\title{
Assessing Growth Performance and Yields of Spinach (Spinacia Oleracea L.) Irrigated with Sea Water
}

\author{
Sema KALE CELIK ${ }^{1 *}$ \\ Büșra DEMIRBAȘ ${ }^{1}$ \\ 'Isparta University of Applied Science, Agricultural Faculty, Agricultural Structure and Irrigation Department, Turkey
}

\author{
*Corresponding author e-mail : semakale@isparta.edu.tr \\ Received : 18.08.2021 \\ Accepted : 24.08.2021 \\ DOI:10.21657/topraksu. 984152
}

\begin{abstract}
This study was carried out to determine the utilization possibility of sea water in spinach plant cultivation, and to evaluate the effect on yield and growth parameters of spinach irrigated with sea water diluted at different rates. The experiment consists of 5 different irrigation water salinity. The tap water was taken as a control (T1; $0.33 \mathrm{dS} / \mathrm{m})$, and 10\% (T2;4 dS/m), 20\% (T3; 7 dS/m), 30\% (T4; $10 \mathrm{dS} / \mathrm{m})$ and 40\% (T5; 13 $\mathrm{dS} / \mathrm{m}$ ) rate of sea water diluted with tap water. According to results, the highest average fresh yield and dry matter values were obtained at T2 (\%10) seawater treatment. Both T2 (10\%) and T3 (20\%) seawater treatments lead to increased fresh yields and dry matter compared to control conditions (T1). While using dilution 10\% and \%20 seawater for irrigation fresh yields increased approximately $27 \%$ and $8.5 \%$ respectively but when irrigated with $30 \%$ and $40 \%$ yields decreasing about $28 \%$ and $72 \%$ respectively. As with the yield results, the $4 \mathrm{dS} / \mathrm{m}$ seawater salinity level caused an increase in leaf heights and leaf number compared to the control treatment. In conclusion, this study shows that seawater can be used successfully when diluted $10 \%$ with good quality water without affecting the growth parameters and yields of spinach.
\end{abstract}

Keywords: Sea water irrigation, salt stress, spinach yield, salinity

\section{Deniz Suyuyla Sulanan Ispanağın (Spinacia Oleracea L.) Büyüme Performansının ve Veriminin Değerlendirilmesi Öz}

Bu çalıșma, deniz suyunun ıspanak yetiștiriciliğinde kullanılabilirliğini belirlemek ve farklı oranlarda sulandırımıș deniz suyu ile sulanan ıspanak bitkisinin verim ve büyüme parametrelerine olan etkisini değerlendirmek amacıyla yapılmıștır. Deneme 5 farklı sulama suyu tuzluluğundan olușmaktadır. Musluk suyu kontrol olarak alınmıș (T1; 0.33 dS/m), ve 10\% (T2;4 dS/m), 20\% (T3; 7 dS/m), 30\% (T4; $10 \mathrm{dS} / \mathrm{m})$ ve $40 \%$ (T5; $13 \mathrm{dS} / \mathrm{m})$ oranlarında deniz suyu çeșme suyu ile seyreltilmiștir. Sonuçlara göre; en yüksek ortalama ıspanak verimi ve kuru madde değerleri T2 (\%10) deniz suyu konusunda elde edilmiștir. Hem \%10 hem de \%20 oranlarında seyreltilmiș deniz suyu uygulanan konulardan, kontrol konusuna göre daha yüksek verim ve kuru madde elde edilmiștir. \%10 ve \%20 oranlarında seyreltilmiș deniz suyu kullanıldığında verim değerleri yaklașık \%27 ve \%8.5 artarken, \%30 ve \%40 oranında sulandırılığında verim değerleri \%28 ve \%72 oranında azalmıștır. Verim sonuçlarında olduğu gibi, 4 dS/m deniz suyu tuzluluk seviyesi (T2) kontrol konusuna kıyasla yaprak yüksekliklerinde ve yaprak sayısında artıșa neden olmuștur. Sonuç olarak, bu çalıșma, deniz suyunun iyi kalite su ile \% 10 düzeyinde seyreltildiğinde ıspanağın büyüme parametrelerini ve verimlerini etkilemeden bașarıyla kullanılabileceğini göstermektedir.

Anahtar kelimeler: Deniz suyu ile sulama, tuz stresi, ispanak verimi, tuzluluk 


\section{INTRODUCTION}

Due to the global warming that has continued to increase in recent years, the whole world is faced with serious problems in terms of water resources. FAO estimates that by 2050 , the world will need to produce sixty percent more food to feed its growing human population. In order to increase food production, a fifty percent increase in irrigated cultivation is required. However, existing water resources allow for an increase of only ten percent (FAO, 2017). For this reason, it is necessary to produce different solutions to meet insufficient water resources especially in regions located in arid and semi-arid climate zones such as our country. There is an increasing awareness among scientists and decision makers about the use of seawater (at least diluted) to reduce the supply of fresh water to be used for agricultural irrigation (FarhadiMachekposhti et al., 2017; Ghassemi Sahebi et al., 2020; Bianciotto et al., 2021).

The high concentration of salts in seawater is the main limiting factor in the utilization of seawater for irrigation. Plants are damaged by salts due to osmotic effects and specific ion toxicity or their combination (Ayers and Westcot, 1989; Nandwal et al., 2000; El-Mahrouk et al., 2010). These factors cause adverse effects on plant growth and yield and these reductions vary according to plant species (Ayers and Wescot, 1976).

Spinach is a moderately salt-tolerant glycophyte and irrigation water salinity threshold level is 2.0 $\mathrm{dS} / \mathrm{m}$. According to some studies on spinach, 25\% and $50 \%$ yield reduction occurs when irrigation water salinity (ECi) is about $3.5 \mathrm{dS} / \mathrm{m}$ and 5.7 $\mathrm{dS} / \mathrm{m}$ respectively. It is determined that almost no yield can be obtained with irrigation water salinity higher than $15 \mathrm{dS} / \mathrm{m}$ (Ayers and Westcot, 1989; Hoffman et al., 1992; Grieve et al., 2012).

However, in a study by Ferreia et al. (2018), it was stated that although increasing amounts of $\mathrm{Na}$ and $\mathrm{Cl}$ accumulate in the leaves according to the physiological and genetic data of the spinach plant applied with salt water, it did not show toxicity even in irrigation water with an $\mathrm{ECi}$ of about $10 \mathrm{dS} / \mathrm{m}$.

It is possible to find several scientific papers (Delfine et al., 2003; Ors and Suares, 2016; Erdem and Kale Celik, 2017; Ünlükara et al., 2017; Deveci and Tugrul, 2017; Ferreira et al.,2020; Uçgun et al., 2020) related to biochemical, physiologșical and moleculer mechanisms of spinach growing under salinity stress. Only in recent years, the effects of alternative water sources such as sea water on commercial plants have begun to be investigated. Turan et al., 2014 carried out a study to investigate the effects of irrigating lettuce (Lactuca sativa L. Cv. Funly) with different concentrations of diluted seawater $10 \%, 2.5 \%, 5 \%$, $10 \%, 15 \%, 20 \%)$ on the fresh yield, marketable yield and quality parameters. The results of this study demonstrated that low concentrations of seawater are suitable for lettuce production and lettuce can be grown successfully using diluted seawater at concentrations of $2.5 \%$ and $5 \%$.

In another study, irrigation with diluted seawater improved the nutritional value and quality of cherry tomatoes (Sgherri et al., 2008). In addition, diluted seawater in the growing medium has also been shown to increase plant water use efficiency (Atzori et al., 2017).

The aim of this study determines using possibility of seawater for the cultivation of spinach and evaluate of changes that may occur in yield and growing parameters of spinach irrigated with different diluted seawater.

\section{MATERIAL AND METHOD}

\subsection{Material}

The experiment was carried out in a greenhouse located on Agricultural Research and Application Center of Isparta University of Applied Sciences

Table 2.1. Some physical and chemical properties of the experimental soil

Çizelge 2.1. Deneme toprağının bazı fiziksel ve kimyasal özellikleri

\begin{tabular}{lc}
\hline Parameters & Value \\
\hline $\mathrm{pH}$ & 7.15 \\
$\mathrm{EC}(\mathrm{dS} / \mathrm{cm})$ & 0.146 \\
Saturation (\%) & 45.00 \\
Field capacity $(\%)$ & 24.30 \\
Wilting point $(\%)$ & 12.86 \\
Bulk density $\left(\mathrm{g} / \mathrm{cm}^{3}\right)$ & 1.15 \\
Organic matter $(\%)$ & 1.65 \\
Lime $(\%)$ & 26.44 \\
Sand $(\%)$ & 35.00 \\
Clay $(\%)$ & 41.00 \\
Loam $(\%)$ & 24.00 \\
Texture & Clay Loam \\
\hline
\end{tabular}


Table 2.2. Chemical composition of irrigation water

Çizelge 2.2. Sulama suyunun kimyasal içeriği

\begin{tabular}{lcccccccccc}
\hline & & \multicolumn{3}{c}{ Soluable cations (meq/L) } & \multicolumn{5}{c}{ Soluable anions (meq/L) } & \\
\cline { 3 - 10 } EC (dS/m) & $\mathrm{DH}$ & $\mathrm{Ca}$ & $\mathrm{Mg}$ & $\mathrm{Na}$ & $\mathrm{K}$ & $\mathrm{CO}_{3}$ & $\mathrm{Cl}$ & $\mathrm{SO}_{4}$ & $\mathrm{HCO}_{3}$ & SAR \\
\hline 33 (seawater) & 8.6 & 20.55 & 107.5 & 195 & 10.55 & 25 & 150 & 110.6 & 48 & 24.37 \\
0.3 (tap water) & 7.4 & 0.98 & 1.2 & 0.2 & 0.8 & 0 & 0.97 & 1.01 & 1.2 & 0.19 \\
4 & 8.2 & 5.89 & 15.62 & 19.68 & 1.78 & 5.3 & 28.71 & 3.08 & 5.88 & 6.00 \\
7 & 8.3 & 8.60 & 26.00 & 32.00 & 5.20 & 6.1 & 41.58 & 15.53 & 8.59 & 7.69 \\
10 & 8.3 & 12.20 & 35.20 & 52.36 & 6.20 & 7.4 & 49.21 & 41.57 & 7.78 & 10.76 \\
13 & 8.4 & 15.20 & 49.30 & 68.76 & 7.80 & 8.6 & 42.50 & 81.86 & 8.10 & 12.11 \\
\hline
\end{tabular}

(37 $77^{\prime} \mathrm{N}, 30^{\circ} 54^{\prime} \mathrm{E}$ ) in Mediterranean Region of Turkey. In the experiment, plastic pots with a diameter of $17 \mathrm{~cm}$ and a height of $16 \mathrm{~cm}$ ( volume 3 liter) were used and filled with $2.5 \mathrm{~kg}$ of soil. The experimental soil was taken from Aridisol great soil group. Soil physical and chemical properties were presented in Table 2.1. According to soil fertility analysis results for basal fertilizer, $10 \mathrm{ml}$ NPK (sodium phosphorus potassium, $3.5 \% \mathrm{NH} 4,5.5$ $\% \mathrm{NO}_{3}, 10 \%$ urea $19 \mathrm{~N}-19 \mathrm{P}-19 \mathrm{~K}+$ micro elements) was applied to the pots.

Spinach (Spinacia Oleracea L.) of Matador variety was used in this experiment. This variety is a fast growing, spreading, moderately upright growing variety Its leaves range from light green to dark green, and its shape is elongated oval or round. It is resistant to cold weather and moderately tolerant to salt stress. Spinach, whose leaves are eaten and has a very high nutritional value, is from the chenopodiaoase family. Its scientific name is Spinacea oleracea L. (Oraman, 1968). Three seeds were planted in each pot and irrigated to field capacity with tap water for 15 days and then they were irrigated with various levels of diluted seawater.

The seawater was obtained from Mediterranean Sea in Antalya/Turkey and diluted with tap water. Seawater salinity was measured as $33 \mathrm{dS} / \mathrm{m}$. Portable EC meter (Hanna HI8633) used for measuring irrigation water salinity level before each application. Irrigation water quality parameters were given in Table 2.2.

\subsection{Method}

The experimental design was completely randomized block design with three replications. The experiment consists of 5 different irrigation water salinity. The tap water was taken as a control, and different rate of sea water diluted with tap water (Table 2.3).
Table 2.3. Salinity treatments Çizelge 2.3. Tuzluluk konuları

\begin{tabular}{ccc}
\hline Treatments & Dilution ratio & $\begin{array}{c}\text { EC } \\
\text { (dS } / \mathrm{m})\end{array}$ \\
\hline T1 & 100\% Tap water (Control) & 0.3 \\
T2 & 90\% Tap water + 10\% Sea water & 4.0 \\
T3 & 80\% Tap water + 20\% Sea water & 7.0 \\
T4 & 70\% Tap water + 30\% Sea water & 10.0 \\
T5 & 60\% Tap water + 40\% Sea water & 13.0 \\
\hline
\end{tabular}

Pots were weighed regularly and irrigated when soil moisture content decreased below the $50 \%$ field capacity. 15\% leaching water were applied for all treatments. Plants were irrigated with seawater until harvesting 160 days after sowing). Spinach plant height was measured and plant leaf number were countered before harvesting.

The total weight of the plants was measured, and the total weight was divided by the number of plants to find the average plant fresh yield (gr/plant). Fresh samples were dried in an oven at $70{ }^{\circ} \mathrm{C}$ until they reached a constant weight (approximately 48 hours), and their dry weights were measured.

MINITAB 18 computer package programs were used for statistical analysis of the results from spinach to determine its salinity responses. Three replicates were taken for each measurement and one-way ANOVA was used to identify significant differences according to Tukey's Test ( $P \leq 0.05)$.

\section{RESULTS AND DISCUSSION}

In the study, the effects of diluted seawater salinity at different rates on plant fresh and dry weight, plant height and number of leaves were investigated. 
3.1. The effect of sea water salinity on plant fresh yield and dry matter

Fresh and dry matters of spinach irrigated with diluted sea water were given in Table 3.1.

Table 3.1. Salinity treatments

Çizelge 3.1. Tuzluluk konular

\begin{tabular}{ccc}
\hline Treatments & $\begin{array}{c}\text { Fresh yield } \\
\text { (g/plant) }\end{array}$ & $\begin{array}{c}\text { Dry matter } \\
\text { (g/plant) }\end{array}$ \\
\hline T1 & 45.59 & 3.91 \\
T2 & 57.97 & 4.84 \\
T3 & 49.44 & 4.24 \\
T4 & 32.61 & 3.37 \\
T5 & 12.76 & 1.68 \\
\hline
\end{tabular}

There was a significant quadratic relationship between irrigation water salinity and fresh yield and dry matter (Figure 3.1). The correlation coefficient (R2) was found to be 0.98 for both fresh yield and dry matter values, respectively. According to variance analysis of average plant fresh yield and dry matter values differences in the spinach plant due to different concentrations of seawater are important with a probability of 95\%. Tukey classification, which is one of the multiple comparison methods used to determine the differences between the level averages of the factors, are given on Figure 3.1 with lower case letter.

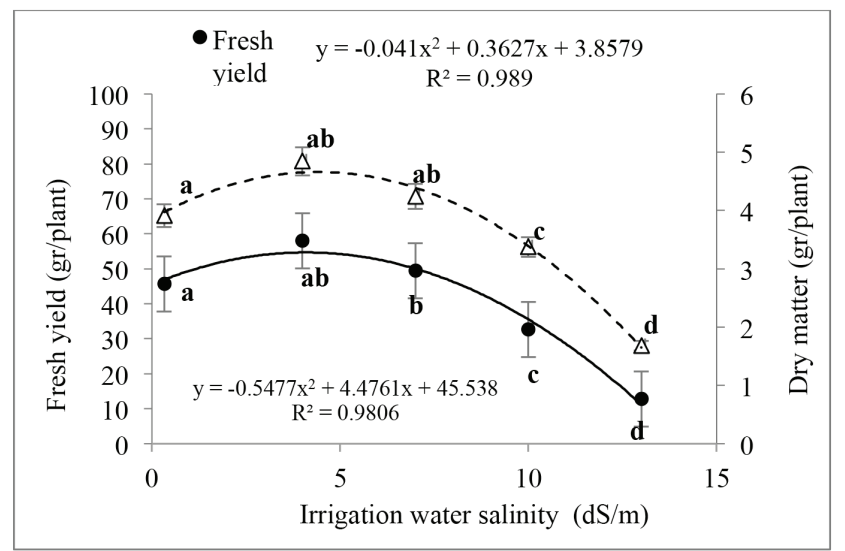

Figure 3.1. Relationships between irrigation water salinity and yield and dry matter

Șekil 3.1. Sulama suyu tuzluluğu ile verim ve kuru madde arasındaki ilișki

The highest average fresh yield and dry matter values were obtained at T2 (\%10) seawater treatment. Both T2 (10\%) and T3 (20\%) seawater treatments lead to increased fresh yields and dry matter compared to control conditions (T1). Relative percentage and differences were calculated and presented Figure 3.2.

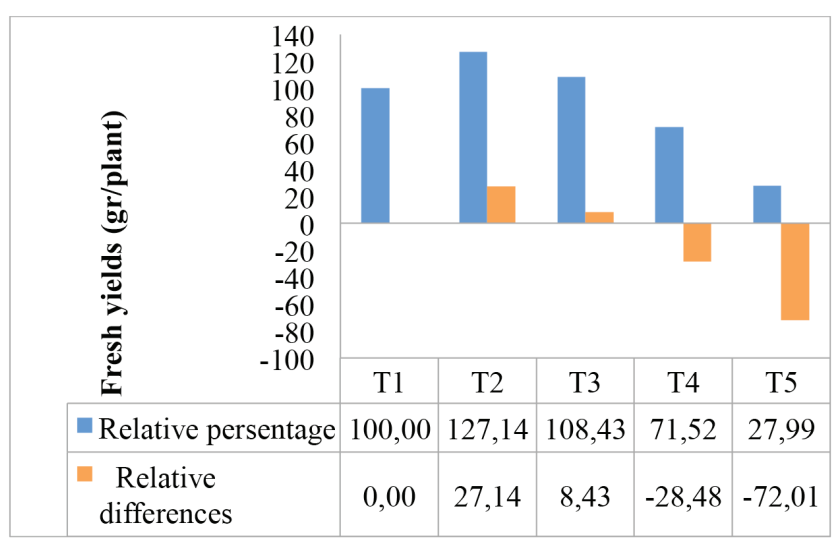

Figure 3.2. Relative percentage and differences of yield according to treatments

Șekil 3.2. Konulara göre nispi verim ve verim farklılıları

While using dilution 10\% and 20\% seawater for irrigation fresh yields increased approximately 27\% and $8.5 \%$ respectively but when irrigated with $30 \%$ and $40 \%$ yields decreasing about $28 \%$ and $72 \%$ respectively. Study results showed good agreement with other experiments conducted using diluted seawater (Caporratta et al., 2019; Ors and Suarez, 2016; Tomemori et al., 2002; Turan et al., 2014). Some scientist reported that diluted seawater becomes an essential source of micro and macro elements that may have a stimulatory effect on plant growth of spinach (Natsheh et al., 2012; Atzori et al., 2016; ElNwehy et al., 2020).

\subsection{The effect of sea water salinity on plant height}

The effects of the applied seawater salinity levels on the plant height were measured and the plant heights according to the treatments were given in Table 3.2.

The increase in the concentration of sea water used as irrigation water caused a decrease in plant height. As seen in Figure 3.3, there is a negative quadratic relationship between treatments and plant height with correlation coefficient 0.86 . 
Table 3.2. Plant heights values of different seawater salinity levels

Çizelge 3.2. Farklı deniz suyu tuzluluklarında bitki boyu değerleri

\begin{tabular}{ccccc}
\hline \multirow{2}{*}{ Treatments } & \multicolumn{4}{c}{ Plant Height $(\mathrm{cm})$} \\
\cline { 2 - 5 } & 1. Replication & 2. Replication & 3. Replication & Average \\
\hline T1 & 13.0 & 14.0 & 14.5 & 13.8 \\
T2 & 15.0 & 16.5 & 12.0 & 14.5 \\
T3 & 10.0 & 8.5 & 7.0 & 8.5 \\
T4 & 8.5 & 6.0 & 9.0 & 7.8 \\
T5 & 5.0 & 6.0 & 6.0 & 5.6 \\
\hline
\end{tabular}

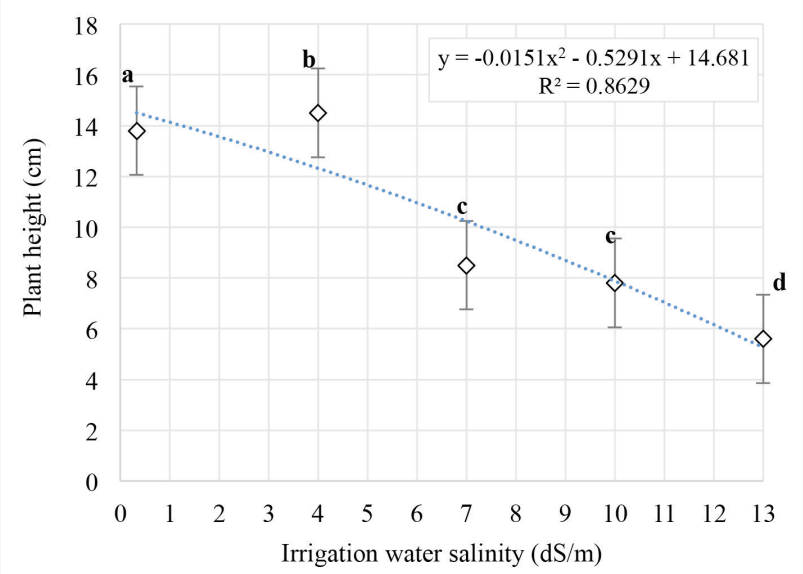

Figure 3.3. Relationships between irrigation water salinity and plant height

Șekil 3.3. Sulama suyu tuzluluğu ile bitki boyu ilișkisi

The results of analysis of variance of average plant heights are shown in Table 3.3.

Table 3.3. Variance analysis table of plant height

Cizelge 3.3. Bitki boyuna ait varyans analizi tablosu

\begin{tabular}{cccccc}
\hline $\begin{array}{c}\text { Source of } \\
\text { variation }\end{array}$ & SD & SS & AS & F & $\frac{\text { Table F }}{0.05} \quad 0.01$ \\
\hline Treatments & 5 & 150.93 & 30.19 & $73.96 *$ & 3.86 \\
Error & 9 & 18.37 & 2.04 & \\
General & 14 & 172.93 & \\
\hline $\begin{array}{l}\text { *; significant level of 0.05, SD; Standard deviation, SS; Sum of square, } \\
\text { AS; Average of square }\end{array}$
\end{tabular}

According to the statistical evaluation, the effect of sea water levels at different concentrations on plant height was found to be significant at the 0.01 level.

3.3. The effect of seawater salinity on the number of leaves

For commercial purposes, leaves are the main component of spinach plant (Atzori et al., 2017; Caparrotta et al., 2019). The effects of seawater salinity levels on the number of plant leaves were evaluated and the average plant leaf numbers according to the subjects are given in Table 3.4.

Table 3.4. The number of plant leaves

Çizelge 3.4. Bitki yaprak sayısı

\begin{tabular}{ccccc}
\hline & \multicolumn{4}{c}{ The number of plant leaves $(\mathrm{cm})$} \\
\cline { 2 - 5 } Treatments & $\begin{array}{l}\text { 1. } \\
\text { Replication }\end{array}$ & \multicolumn{2}{c}{ Replication } & $\begin{array}{c}\text { Replication } \\
\text { Average }\end{array}$ \\
\hline T1 & 12 & 13 & 11 & 12 \\
T2 & 14 & 13 & 12 & 13 \\
T3 & 11 & 10 & 9 & 10 \\
T4 & 8 & 9 & 7 & 8 \\
T5 & 7 & 7 & 7 & 7 \\
\hline
\end{tabular}

The highest average number of plant leaves was obtained in 12 treatment. The average number of plant leaves was T1 (12), T3 (10), T4 (8), and T5 (7), respectively. The variance analysis results of the average plant leaf numbers are shown in Table 3.5.

Table 3.5. The number of plant leaves variance analysis table Cizelge 3.5. Bitki yaprak sayısına ait varyans analizi tablosu

\begin{tabular}{ccccccc}
$\begin{array}{c}\text { Source of } \\
\text { variation }\end{array}$ & SD & SS & AS & F & \multicolumn{2}{c}{ Table F } \\
\hline Treatments & 5 & 40.93 & 8.19 & $32.13 *$ & 3.86 & 0.01 \\
Error & 9 & 11.47 & 1.27 & & & \\
General & 14 & 52.93 & & & & \\
\hline
\end{tabular}

*; significant level of 0.05, SD; Standard deviation, SS; Sum of square, AS; Average of square

There is a significant negative relationship between seawater salinity and the number of plant leaves. This situation can be seen in Figure 3.4.

According to the obtained values, the correlation coefficient $R^{2}=0.98$. As the irrigation water salinity increased, there was a linear decrease in the number of plant leaves. No significant differences in leaves number were assessed among treatments at $\mathrm{T} 4$ and $\mathrm{T} 5$. 


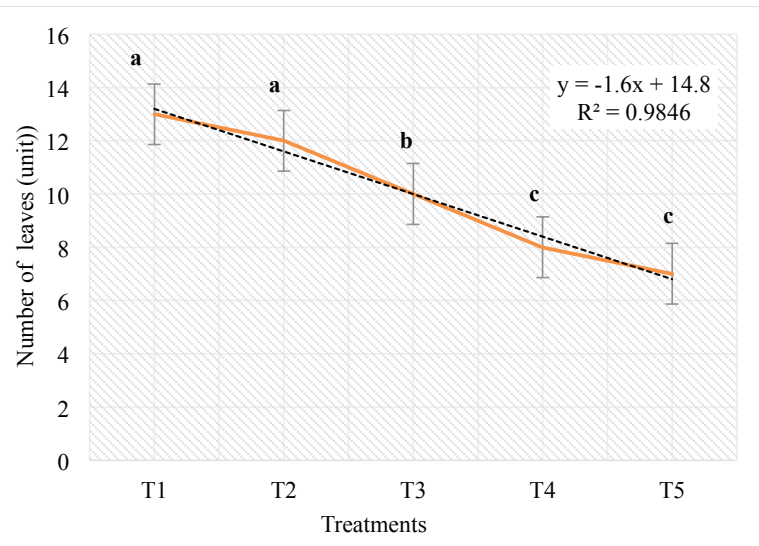

Figure 3.4. Average number of leaves and Tukey classifications

Ssekil 3.4. Ortalama yaprak sayıları ve Tukey sınıflaması

\section{CONCLUSIONS}

Experiment results indicated that more than $10 \%$ diluted seawater application negatively affected of the spinach plant in terms of fresh and dry yields as compared to the control. Both 10\% and 20\% seawater treatments lead to increased relative yields (\%27 and \%8) but 30\% and 40\% diluted seawater treatments decreased relative yields about $28 \%$ and $72 \%$ respectively. As in yield results, significant differences in leave heights and number of leaves were observed, with $4 \mathrm{dS} / \mathrm{m}$ sea water salinity level (T2) compared to the control.

In conclusion, this study indicates that spinach can be successfully cultivated using sea water with moderate salinity (\%10 diluted) without altering its growth parameters and yields.

\section{Acknowledgement}

This study was supported financially by the Scientific and Technological Research Council of Turkey with the project number TÜBITAK 2209/ B011500668. We would like to thank for their supports.

\section{References}

Atzori G, Nissim WG, Caparrotta S, Masi E, Azzarello E, Pandolfi C, Vignolini P, Gonnelli C, Mancuso S (2016). Potential and constraints of different seawater and freshwater blends as growing media for three vegetable crops. Agricultural Water Management, 176: 255-262.

Atzori G, Vos AC, Rijsselberghe M, Vignolini P, Rozema J, Mancusoa S, Bodegomf P (2017). Effects of increased seawater salinity irrigation on growth and quality of the edible halophyte Mesembryanthemum crystallinum L. under field conditions. Agricultural Water Management, 187: 37-46.

Ayers RS, Westcot DW (1976). Water quality for agriculture. FAO Irrigation and Drainage Paper 29: 31-33.
Ayers RS, Westcot DW (1989). Water quality for agriculture. FAO Irrigation and Drainage Paper 29: 1-174.

Bianciotto O, Martin FA, Arce ME, Selzer L, García JO, Paulo G, Cárdenas LAG, Robledo A, Puente EA (2021). Farming with drip sea water irrigation for Salicornia production in Tierra del Fuego. Argentina. Biotecnia / XXIII (1): 77-85.

Caparrotta S, Masi E, Atzori G, Diamanti I, Azzarello E, Mancuso S, Pandolf C (2019). Growing spinach (Spinacia oleracea) with different seawater concentrations: Effects on fresh, boiled and steamed leaves. Scientia Horticulture 256: 10854

Delfine S, Tognetti R, Alvino A, Loreto F (2003). Fieldgrown chard (Beta vulgaris L.) under soil water stress conditions: Effect on antioxidant content proc. XXVI IHCEnvironmental Stress. In: Tanino, K.K. (Ed.), Acta Hortic. 618, ISHS 2003 Publication supported by Can. Int. Dev. Agency (CIDA).

Deveci M, Tuğrul B (2017). The effect of salt stress on leaf physiological properties in spinach. Academic Journal of Agriculture 6: 89-98.

El-Mahrouk M, El-Nady M, Hegazi MA (2010). Effect of diluted seawater irrigation and exogenous proline treatments on growth, chemical composition and anatomical characteristics of Conocarpus Erectus L. Journal Agriculture Research Kafrelsheikh University, 36 (4): 420-446.

El-Nwehy SS, Rezk Al, El-Nasharty AB, Nofal OA, AbdelKade $H$ (2020). Influences of irrigation with diluted seawater and fertilization on growth, seed yield and nutrients status of salicornia plants. Pakistan Journal of Biological Sciences. 23 (10): 1267-1275

Erdem F, Kale Celik S (2017). Effects of irrigation water with different salinity and leaching fraction on spinach (Spinacia oleracea L.) growth, yield and drainage water quality. Süleyman Demirel Üniversity, Journal of Agricultural Faculty. 73-82.

FAO (2017). The future of food and agriculture. Trends and Challenges. p:11-12.

Farhadi-Machekposhti M, Shahnazari A, Ahmadi MZ, Aghajani Gh, Ritzema H (2017). Effect of irrigation with sea water on soil salinity and yield of oleic sunflower. Agricultural Water Management, 188: 69-78.

Ferreira JSF, Sandhu D, Liu X Halvorson JJ (2018). Spinach (Spinacea oleracea L.) response to salinity: Nutritional Value, Physiological Parameters, Antioxidant Capacity, and Gene Expression. Agriculture, 8:163.

Ferreira JFS, Silva JB, Liu X, Sandhu D (2020). Spinach plants favor the absorption of $\mathrm{K}^{+}$over $\mathrm{Na}^{+}$regardless of salinity and may benefit from $\mathrm{Na}^{+}$when $\mathrm{K}^{+}$is deficient in the soil. Plants, 9: 507.

GhassemiSahebia F, Mohammadrezapourb O, Delbaric M, KhasheiSiukid A, Ritzemae H, Cheratif A (2020). Effect of utilization of treated wastewater and seawater with Clinoptilolite Zeolite on yield and yield components of sorghum. Agricultural Water Management, 234: 106-117.

Grieve CM, Grattan SR, Maas EV (2012). Plant salt tolerance. Agricultural Salinity Assessment and Management. Chapter 13: 405-459. 
Hoffman GJ, Rhoades DJ, Letey J (1992). Salinity Management. In: Hoffman GJ, Howell TA, Solomon KH (ed.): Management of Farm Irrigation Systems. ASAE, 667-715.

Natsheh B, Barghouthi Z, Amereih S, Salman M (2012). Effect of Irrigation with sea water on germination and growth of lentil (Lens culinaris Medic). Journal of Water Resource and Protection 4: 307-310.

Nandwal AS, Godara M, Sheokand S, Kamboj DV, Kundu BS, Kuhad MS, Kumar B, Sharma G (2000). Salinity induced changes in plant water status, nodule functioning and ionic distribution in phenotypically differing genotypes of Vigna radiata L. Plant Physiology, 156: 350-359

Oraman N (1968). Sebze ilmi. Ankara University Faculty of Agriculture Publications 323, Ankara.

Ors S, Suarez DL (2016). Salt tolerance of spinach as related to seasonal climate. Horticulture Science, 43: 33-41

Sgherri C, Kadlecová Z, Pardossi A, Navari-lzzo F, Izzo $R$ (2008). Irrigation with diluted seawater improves the nutritional value of cherry tomatoes. Journal of Agricultural and Food Chemistry, 56 (9): 3391-7.
Tomemori H, Hamamura K, Tanabe K (2002). Interactive effects of sodium and potassium on the growth and photosynthesis of spinach and komatsuna. Plant Production Science, 5(4): 281-285.

Turhan A, Kuscu H, Ozmen N, Serbeci MS, Demir AO (2014). Effect of different concentrations of diluted seawater on yield and quality of lettuce. Chilean Journal Of Agricultural Research. 74 (1): 111-116.

Uçgun K, Ferreira JFS, Liu X, Silva Filho JB, Suarez D, Lacerda C, Sandhu D (2020). Germination and growth of spinach under potassium deficiency and irrigation with highsalinity water. Plants 9 (1739): 1-19.

Ünlükara A, Yurtyeri T, Cemek B (2017). Effects of irrigation water salinity on evapotranspiration and spinach (Spinacia oleracea L. Matador) plant parameters in greenhouse indoor and outdoor conditions. Agronomy Research 15 (5): 2183 2194. 